\title{
Fiscal Policy and Unemployment in South Africa: 1980 - 2010
}

\section{Genius Murwirapachena}

Department of Economics, University of Fort Hare

Email:murwiragenius@gmail.com

Ireen Choga

School of Economic \& Decision Sciences, North West University, South Africa (Corresponding Author) Email: Ireen.Choga@nwu.ac.za

\author{
Andrew Maredza \\ School of Economic \& Decision Sciences, North West University, South Africa \\ Email: Andrew.Maredza@nwu.ac.za

\section{Associate Professor Nehemiah Mavetera} \\ School of Economic \& Decision Sciences, North West University, South Africa \\ Email: Nehemiah.mavetera@nwu.ac.za
}

Doi:10.5901/mjss.2013.v4n6p579

\section{Abstract}

Unemployment is one of the most topical challenges facing South Africa. Like most developing countries, South Africa has been using the fiscal policy framework as a tool to alleviate the high rates of unemployment. Despite the government's tremendous effort to influence economic behaviour using an expansionary fiscal policy framework, unemployment has remained a challenging phenomenon in South Africa This study examined the impact of fiscal policy on unemployment in South Africa using annual time series data for the period 1980 to 2010. A vector error correction model was used to determine the effects of fiscal policy aggregates on unemployment in South Africa. Results from this study revealed that government consumption expenditure and tax have a positive impact on unemployment while government investment expenditure negatively affects unemployment in South Africa. The study recommends the South African government to reduce the corporate tax rate from 28 per cent to figures below 20 per cent as adopted by other OECD countries Policy recommendations were made based on these results.

Keywords: Fiscal policy, Unemployment, Vector Error Correction, South Africa.

\section{Introduction}

The role of government in the economy has always been a topical issue for debate. Some economic agents argue against large governments while others believe that without the government taking a more active and participatory role to steer the economy, countries could move from unstable growth to prolonged recessions and massive rates of unemployment. Accordingly, there is a growing interest and debate about the effects of fiscal policy on unemployment. Theorists and researchers have come up with conflicting conclusions regarding these two economic phenomena. This study therefore seeks to contribute to the debate by examining the impact of fiscal policy on unemployment in South Africa.

Since 1980, the South African government has used fiscal policy as a tool to influence the level of economic behaviour in an effort to achieve the economic objective of full employment, among others. The period up to 2010 was dominated by several years of an expansionary fiscal policy stance which saw the government constantly advocating for national budget deficits. Budget deficit as a percentage of GDP rose from about 1.3 per cent in 1980 to about 4.8 per cent in 2010, averaging about 2.8 per cent for the period 1980 to 2010 (DTI, 2011). Over the period 1980 to 2010, only two fiscal years (2007 and 2008) recorded budget surpluses of 0.3 per cent and 0.7 per cent of GDP respectively. 
Despite the government's tremendous effort to influence economic behaviour using an expansionary fiscal policy framework, unemployment has remained a challenging phenomenon in South Africa. High levels of unemployment have always been recorded in the country over the years (Barker, 2007). Before 1994, unemployment was dominant among the black South Africans due to the discriminatory labour market practises. According to Woolard (2002) the massive investment in state education for white school-children in the 1950s and 1960s resulted in white workers securing the skills that enabled them to get high income jobs in the 1970s and 1980s without the need for policies such as job reservation. Restrictive past economic practices thus prevented much of the population from vertical mobility within the labour market. Over the period 1980 to 2010 , an upward trend in unemployment was observed. The unemployment rate increased from 9.8 per cent in 1980 to 30.4 per cent in 2002 before decreasing to 26.1 per cent in 2010.

Considering the fiscal policy framework adopted by the government over the years, it is imperative to ask how this has transformed unemployment in the country. The questions that basically come to mind are: Did the expansionary fiscal policy stance manage to alleviate unemployment? What are the consequences of such a fiscal policy stance relative to unemployment? Therefore, this study seeks to examine the impact of fiscal policy on unemployment in South Africa. Specifically, the study examines the impact of government expenditure and tax on unemployment.

This paper is structured as follows: Section Two presents a brief overview of trends in the behaviour of fiscal policy and unemployment in South Africa over the period 1980 to 2010. Section Three provides an overview of supporting theoretical and empirical literature. Section Four discusses the methodology and the sources of data, where as Section Five estimates the regression model and discusses the results of the study. Section Six concludes the study and presents some policy recommendations.

\section{An Overview of Fiscal Policy and Unemployment in South Africa}

South Africa has been using a counter-cyclical fiscal policy which enables the government to respond flexibly to the effects of the economic cycle (Treasury, 2009). This stance allows the government to borrow in a way that requires it to save temporary revenue gains when the economy is strong, and to borrow to compensate for temporary revenue losses when the economy is weak. In the period 1980 to 2010, fiscal trends in South Africa show government expenditure exceeding government revenue except in 2007 and 2008 when the government recorded respective budget surpluses of R22 777 million and R34 400 million (0.3 per cent and 0.7 per cent of GDP). On the other hand, unemployment continues to be one of the greatest and most complex challenges facing South Africa. According to Treasury (1998), the number of people without formal sector employment continues to rise as the number of work-seekers that enter the labour force each year exceeds the number of new formal sector employment opportunities. The unemployment rate increased from 9.8 per cent in 1980 to 26.1 per cent in 2010, averaging 21.7 per cent over the years (StatSA, 2010). The trends in fiscal policy and unemployment in South Africa are illustrated in Figure 1.

Figure 1: Trends in fiscal policy and unemployment in South Africa (1980 to 2010)

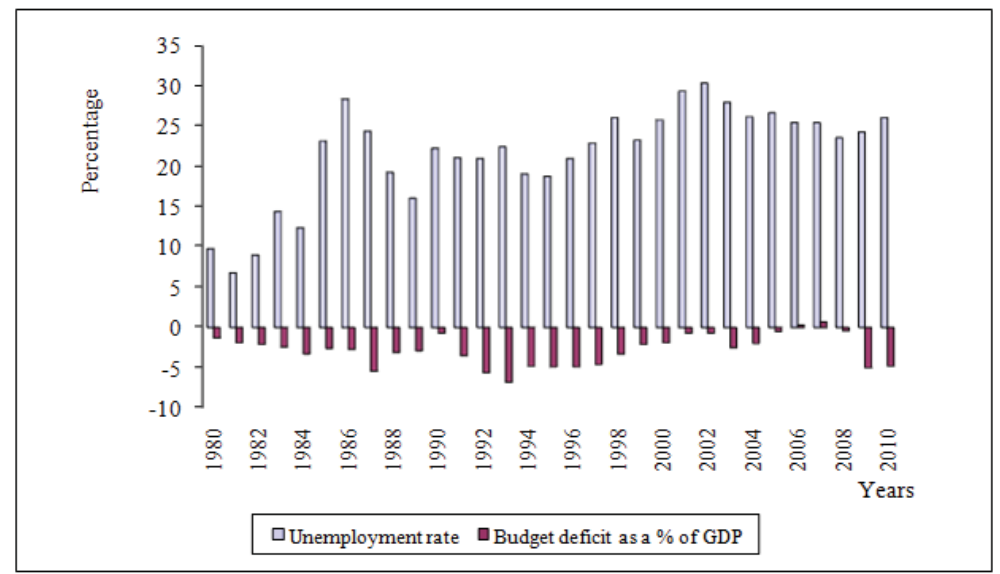

Source: Own computations with data from the DTI (2011) 
Figure 1 shows that the budget deficit as a percentage of GDP rose from 1.3 per cent in 1980 to about 4.8 per cent in 2010. The 1993 fiscal year recorded the highest budget deficit of 6.8 per cent; whereas in 2007 and 2008 the treasury recorded respective budget surpluses of 0.3 and 0.7 per cent. Equally, Figure 1 also shows the unemployment rate increasing from 9.8 per cent in 1980 to 26.1 per cent in 2010, averaging 21.7 per cent over the years. The year 1981 recorded the lowest unemployment rate of 6.1 per cent, while the highest rate of unemployment (30.4 per cent) was recorded in 2002. This brief background leads to a discussion of supporting literature.

\section{A Review of Supporting Literature}

This study is anchored by several economic theories which include: Keynes' (1936) theory of unemployment, Musgrave's (1959) fiscal policy theory, Buchanan and Tullock's (1962) public choice theory; and Friedman's (1969) natural rate theory. The theory of fiscal policy agreed with the Keynesian role of fiscal policy on the assumption that policymakers have no other objectives beside the promotion of social welfare. Differently, the public choice theory assumed politicians to be people who use the fiscal policy framework to maximise their personal welfare, as opposed to social welfare. The natural rate theory assumes that changes in aggregate demand may cause the levels of output and employment to return to their natural rate over a longer period.

Previous researchers conducted several studies regarding the relationship between fiscal policy and unemployment. However, assorted results were observed due to the country or countries researched, methods used and the data employed. Research conducted in developed countries includes the work of Rose (1981), Tanzi and Zee (1997), Fatas and Mihov (1998), Abrams (1999), Kneller, Bleaney and Gemmell (1999), Hercowitz and Strawczynski (2004), and Feldmann (2006). To examine the relationship between fiscal policy and the behaviour of unemployment in developing countries, various researches have also been conducted. These include studies by Aizenman and Marion (1993), Giavazzi, Jappelli, and Pagano (2000), Brett (2005), Pepinsky (2007), Agénor, Nabli, Yousef, and Jensen (2007), Schclarek (2007), and Zenou (2008). Although a large gap of literature exists in South Africa, various researchers have tried to model fiscal policy and unemployment in the country. Notable researchers who contributed to the South African literature include but not limited to: Stryker, Cassim, Rajaratnam, Bhorat, Leibbrandt, and Plunkett (2001), Agénor (2004), Kingdon, and Knight (2007), Banerjee, Galiani, Levinsohn, McLaren and Woolard (2008), and Klasen and Woolard (2008). The next section discusses the methodology used for this study.

\section{Methodology}

To estimate the impact of fiscal policy on unemployment in South Africa, this study uses a vector autoregression (VAR) model. Data is firstly tested for stationarity using the Dickey-Fuller and the Augmented-Dickey Fuller tests. Subsequently, the Johansen $(1991,1995)$ cointegration technique is used to test for cointegration, after which a vector error correction model (VECM) is used to estimate the long run equation and the existence of error correction. Diagnostic checks are also performed to test for normality (Jarque-Bera), heteroskedacity (White test) and serial correlation (Lagrange Multiplier). Finally, impulse response analysis and variance decomposition are performed to respectively examine the impact of fiscal policy variables on unemployment in South Africa; and the proportion of forecast error variance in unemployment that is explained by its innovations and those of the fiscal policy aggregates.

\section{The Model}

This study adopted the model outlined in Baxter and King (1993) as discussed further by Fatas and Mihov (2001) who regressed employment against fiscal and non fiscal variables. The model is modified to test for the effects of fiscal policy on unemployment in South Africa. Unemployment is modelled as a function of fiscal policy variables (government consumption spending, government investment spending and tax). This is expressed as follows:

$$
\text { UNEMPLOY }=\beta_{0}-\beta_{1} \text { GOVSPEND }-\beta_{2} \text { GOVIN }+\beta_{3} \text { TAX }+\mu
$$

A description of all variables that appear in the estimated equation is provided as a way to avoid the misconception of empirical results. The variables are converted to logarithms so as to remove trends. The model (in equation 1) thus assumes the form: 
LnUNEMPLOY $=\beta_{0}-\beta_{1} \operatorname{LnGOVSPEND}-\beta_{2} \operatorname{LnGOVIN}+\beta_{3} \operatorname{LnTAX}+\mu$

Where:

LnUNEMPLOY = Logarithm of unemployment based on the strict definition unemployment rate.

LnGOVSPEND = Logarithm of the aggregate government consumption expenditure. The study uses final consumption expenditure by general government at constant 2000 prices.

LnGOVIN = Logarithm of gross fixed capital formation used as proxy for government investment

$\operatorname{LnTAX}=$ Logarithm of tax, current tax on income and wealth at current prices is used as a proxy for tax. This is used because it is difficult to obtain time series data of consolidated government tax collections.

$\mu=$ an error term.

The study uses annual time series data covering the period 1980 to 2010. Data on fiscal policy aggregates is obtained from the electronic database of the Department of Trade and Industry (DTI) while data on unemployment is obtained from Statistics South Africa (StatSA). To avoid the possibility of drawing up conclusions based on statistically spurious relationships, all data series were tested for stationarity. The Dickey-Fuller and Augmented Dickey-Fuller unit root tests were used and test results are presented in Table 1. For the most part, both the Dickey-Fuller and the Augmented Dickey-Fuller results suggested that the null hypothesis of the presence of unit root in the variables in levels could not be rejected at $1 \%$ significance level indicating that the variables are non-stationary in levels. However, when the variables are first differenced the null hypothesis of the unit root in each of the series was rejected at $1 \%$ significance level. Therefore it can be concluded that all the variables are integrated of order one.

Table 1: Unit Root Tests Results

\begin{tabular}{|c|c|c|c|c|}
\hline & Unemployment & $\begin{array}{l}\text { Government } \\
\text { Spending }\end{array}$ & $\begin{array}{l}\text { Government } \\
\text { Investment }\end{array}$ & Tax \\
\hline \multicolumn{5}{|l|}{ ADF } \\
\hline Level & 2.330779 & 2.112135 & 0.793607 & 1.974290 \\
\hline First Difference & $5.961483^{\star \star *}$ & $2.943622^{*}$ & $3.892329^{* * *}$ & $4.000306^{\star * \star}$ \\
\hline \multicolumn{5}{|l|}{ PP } \\
\hline Level & 2.282226 & 0.962454 & 0.301914 & $6.615053^{\star * \star}$ \\
\hline First Difference & $5.932224^{\star \star *}$ & $2.977616^{\star \star}$ & $4.163685^{* \star *}$ & $3.744335^{* \star \star}$ \\
\hline
\end{tabular}

\section{Main Findings}

Given that variables in this study are integrated of the same order, cointegration tests are performed to determine the existence of a long-run equilibrium relationship amongst the variables. Cointegration of variables means that the linear combination of the variables is stationary even though the individual variables will be non-stationary. The Johansen's $(1991,1995)$ maximum likelihood approach was used to test for cointegration.

Before performing cointegration tests, the study used the pair-wise correlation matrix to guide on the variable selection exercise. Table 2 shows results of the pair-wise correlation matrix used to determine the relationship between the four variables involved in this study. Results from the correlation matrix showed that all the explanatory variables except for government investment expenditure are positively correlated with unemployment. This means that high values of government consumption and tax are likely to be associated with high values of unemployment in South Africa.

Table 2: Pair-wise correlation results

\begin{tabular}{|l|c|c|c|c|}
\hline & UNEMPLOY & GOVIN & GOVSPEND & TAX \\
\hline UNEMPLOY & 1.00 & -0.29 & 0.68 & 0.74 \\
\hline GOVIN & -0.29 & 1.00 & 0.22 & 0.05 \\
\hline GOVSPEND & 0.67 & 0.22 & 1.00 & 0.95 \\
\hline TAX & 0.74 & 0.06 & 0.95 & 1.00 \\
\hline
\end{tabular}

The Johansen cointegration technique used in this study also requires an indication of the lag order and the deterministic trend assumption of the VAR before performing cointegration tests. The information criteria approach is applied as a 
direction to choose the lag order. In this study, the selection is made using a maximum of 3 lags in order to permit for adjustments in the model and accomplish well behaved residuals. Table 3 presents results for the lag length selection criteria which showed that all the criteria selected 1 lag. Therefore, the Johansen cointegration test is performed using 1 lag for the VAR.

Table 3: Lag order selection criteria

\begin{tabular}{|c|c|c|c|c|c|c|}
\hline Lag & LogL & LR & FPE & AIC & SC & HQ \\
\hline 0 & 106.2145 & NA & $7.93 \mathrm{e}-09$ & -7.301036 & -7.110721 & -7.242854 \\
\hline 1 & 257.6708 & $248.8211^{*}$ & $5.06 \mathrm{e}-13^{*}$ & $-16.97649^{*}$ & $-16.02491^{*}$ & $-16.68558^{*}$ \\
\hline 2 & 268.9879 & 15.35889 & $7.65 \mathrm{e}-13$ & -16.64199 & -14.92916 & -16.11836 \\
\hline 3 & 279.1943 & 10.93544 & $1.43 \mathrm{e}-12$ & -16.22817 & -13.75407 & -15.47181 \\
\hline
\end{tabular}

\section{Notes}

* indicates lag order selected by the criterion

LR: sequential modified LR test statistic (each test at $5 \%$ level)

FPE: Final prediction error

AIC: Akaike information criterion

SC: Schwarz information criterion

$\mathrm{HQ}$ : Hannan-Quinn information criterion

Results from the much stricter Johansen cointegration trace test in Appendix Table 4 reflected that at least one cointegrating equation exist at $5 \%$ significance level. The null hypothesis of no cointegrating vectors is rejected since the trace (test) statistic of 52.51 is greater than the critical value of approximately 47.86 at $5 \%$ significance level. However, the maximum eigenvalue test in Table 4 revealed that there are no cointegrating equations at $5 \%$ significance level. This is because the test statistics are smaller than the critical values. Using the maximum eigenvalue test, we fail to reject the null hypothesis that there is no cointegration at $5 \%$ significance level. Therefore, it can be concluded that there is one significant long run relationship between the variables (using trace test results). Since variables can either have short or long run effects, a vector error correction model (VECM) is used to disaggregate these effects.

Table 4: Cointegration Rank Test (Trace) Results

\begin{tabular}{|c|c|c|c|c|}
\hline Hypothesised No. Of CE(s) & Eigenvalue & Trace Statistic & 0.05 Critical Value & Prob $^{\star \star}$ \\
\hline None $^{*}$ & 0.551866 & 52.51157 & 47.85613 & 0.0171 \\
\hline At most 1 & 0.432243 & 29.23433 & 29.79707 & 0.0580 \\
\hline At most 2 & 0.330640 & 12.81852 & 15.49471 & 0.1216 \\
\hline At most 3 & 0.039772 & 1.176937 & 3.841466 & 0.2780 \\
\hline
\end{tabular}

Table 5: Cointegration Rank Test (Maximum-Eigenvalue) Results

\begin{tabular}{|l|c|c|c|c|}
\hline Hypothesised No. Of CE(s) & Eigenvalue & Max-Eigen Statistic & 0.05 Critical Value & Prob. $^{* *}$ \\
\hline None & 0.551866 & 23.27723 & 27.58434 & 0.1619 \\
\hline At most 1 & 0.432243 & 16.41581 & 21.13162 & 0.2015 \\
\hline At most 2 & 0.330640 & 11.64158 & 14.26460 & 0.1248 \\
\hline At most 3 & 0.039772 & 1.176937 & 3.841466 & 0.2780 \\
\hline $\begin{array}{l}\text { Max-eigenvalue test indicates no cointegration at the 0.05 level } \\
\text { *denotes rejection of the hypothesis at the 0.05 level } \\
\text { **MacKinnon-Haung-Michelis (1999) p-values }\end{array}$ \\
\hline
\end{tabular}

A vector error correction model (VECM) is useful when distinguishing between the long and short run impacts of variables so as to establish the extent of influence that the fiscal policy aggregates have on unemployment. The long run impact of fiscal policy aggregates on unemployment in South Africa as shown in Table 6 is illustrated using equation 3: 
Table 6: Long run cointegrating equation results

\begin{tabular}{|l|c|c|c|}
\hline Variable & Coefficient & Standard error & t-statistic \\
\hline Constant & -10.624 & - & - \\
\hline UNEMPLOY(-1) & 1.000 & - & - \\
\hline GOVIN(-1) & -0.782 & 0.365 & -2.142 \\
\hline GOVSPEND(-1) & -3.013 & 1.455 & -2.071 \\
\hline TAX(-1) & +0.619 & 0.266 & +2.329 \\
\hline
\end{tabular}

UNEMPLOY $=-10.624-0.782$ GOVIN -3.013 GOVSPEND +0.619 TAX

Equation 3 suggests that GOVIN and GOVSPEND have a negative long run relationship with UNEMPLOY, while TAX has positive relationship. All the variables are statistically significant in explaining unemployment since their absolute tvalues are greater than 2. The results suggest that a unit increase in GOVIN reduces unemployment by approximately 0.78 while a unit increase in GOVSPEND decreases unemployment by approximately 3.01. A unit increase in TAX increases unemployment by approximately 0.62 ; and vice-versa. The negative impact of GOVIN and GOVSPEND on unemployment is compatible with economic theory.

Moreover, the VECM results suggested evidence of error correction as shown in Appendix Table 7. The coefficient of the differenced dependent variable $(-0.316)$ is statistically significant with a t-value of approximately -3.738 . This shows that the speed of adjustment is approximately $31.6 \%$; implying that if there is a deviation from equilibrium, approximately $31.6 \%$ of unemployment is corrected in one year as the variable moves towards restoring equilibrium. Therefore, this means there is no strong pressure on unemployment to restore long run equilibrium whenever there is a disturbance. The result presented in Table 7 ind-icates that all explanatory variables included in the model are significant with a tstatistic above 2 with the exception of a constant term. The error correction results also suggest that a 1 per cent increase in government investment has the effect of reducing unemployment by 0.069 percent. It is worth mentioning that of the included determinant factors government investment has the greatest impact on unemployment in South Africa. A coefficient of -0.019 on government expenditure implies that a 1 percent increase in government expenditure decreases unemployment by 0.019 percent. The findings of the study presented in Table 7 suggest that a 1 percent increase in income tax will increase unemployment by 0.015 per cent.

Table 7: Error correction results

\begin{tabular}{|l|c|c|c|}
\hline Variable & Coefficient & Standard error & t-statistic \\
\hline D(UNEMPLOY) & -0.316 & 0.085 & -3.738 \\
\hline D(GOVIN)(-1) & -0.069 & 0.0265 & -2.603 \\
\hline D(GOVSPEND)(-1) & -0.019 & 0.00798 & -2.378 \\
\hline D(TAX)(-1) & +0.015 & 0.00617 & +2.431 \\
\hline
\end{tabular}

To validate the parameter evaluation of the outcomes achieved by the model used in this study, diagnostic checks were performed. The model was tested for fitness using three main tests, these are, the langrage multiplier (LM) test for serial correlation, the White test for heteroskedesticity and the Jarque-Bera test for normality. Results presented in Table 8 suggested that there is no serial correlation, there is no conditional heteroskedesticity, and there is a normal distribution in the unemployment model.

Table 8: Diagnostic checks results

\begin{tabular}{|l|l|c|c|}
\hline Test & Null Hypothesis & t-Statistic & Probability \\
\hline Langrage Multiplier (LM) & No serial correlation & 12.144 & 0.734 \\
\hline White (CH-sq) & No conditional heteroskedesticity & 88.082 & 0.251 \\
\hline Jarque-Bera (JB) & There is a normal distribution & 0.265 & 0.876 \\
\hline
\end{tabular}

Following suggestions by Blanchard (1987) this study also performed Impulse Response and Variance Decomposition which provide useful econometric inferences about the whole system as well as exhausting descriptions of the dynamic 
properties of the system. Since the study focuses on the impact of fiscal policy on unemployment, only the impulse response functions and variance decompositions of unemployment to the fiscal policy aggregates are reported.

Impulse response functions in Appendix Figure 1 show the dynamic response of unemployment to a one-period standard deviation shock of the system and also indicate the directions and persistence of the response to each of the shocks over a 10 year period. The functions suggest that shocks to all the variables are significant although they are not persistent. A one-period standard deviation shock to GOVIN and TAX marginally appreciates unemployment by about 3 per cent each but the impact dies off quickly in a period of about 6 years. Furthermore, a one period standard deviation shock to GOVSPEND depreciates unemployment by about 3 per cent, but also gradually levels off in about 6 years. This result suggests that an expansionary fiscal policy depreciates unemployment by 3 per cent, while results on GOVIN and TAX implied that an increase in both variables appreciates unemployment by 3 per cent on average.

The study also performed variance decomposition for 10 years in order to ascertain the effects when the fiscal policy aggregates are allowed to affect unemployment for a relatively longer time. Variance decomposition results in Table 9 revealed that in the first year, all of the variance in unemployment is explained by its own innovations (shocks). In the $5^{\text {th }}$ year ahead, unemployment itself explains 81 per cent of its variation, while fiscal policy aggregates explain the remaining 19 per cent. Of this 19 per cent, GOVIN explains 4.7 per cent, GOVSPEND explains 5.5 per cent and TAX explains 8.5 per cent. However, in the $10^{\text {th }}$ year, unemployment explains 58 per cent of its own variation, while fiscal policy aggregates explain the remaining 42 per cent. The influence of GOVIN substantially increases to 12 per cent, while GOVSPEND increases to 13.8 per cent and TAX increases to 15.5 per cent. These results are compatible with economic theory as shocks to fiscal policy aggregates continue to explain a significant proportion of the variation in unemployment.

Table 9: Variance Decomposition of Unemployment.

\begin{tabular}{|c|c|c|c|c|c|}
\hline Period & S.E & UNEMPLOY & TAX & GOVSPEND & GOVIN \\
\hline 1 & 0.070188 & 100.0000 & 0.000000 & 0.000000 & 0.000000 \\
\hline 2 & 0.085374 & 97.76786 & 1.684770 & 0.353333 & 0.194038 \\
\hline 3 & 0.093945 & 95.71220 & 3.408841 & 0.407399 & 0.471555 \\
\hline 4 & 0.101601 & 89.87275 & 5.867458 & 1.672979 & 2.586810 \\
\hline 5 & 0.110694 & 81.22013 & 8.511023 & 3.980740 & 6.288104 \\
\hline 6 & 0.120789 & 72.92995 & 10.78120 & 6.245927 & 10.04292 \\
\hline 7 & 0.130852 & 66.71751 & 12.49274 & 7.872349 & 12.91740 \\
\hline 8 & 0.140263 & 62.61758 & 13.71405 & 8.853907 & 14.81446 \\
\hline 9 & 0.148856 & 60.03545 & 14.58028 & 9.395878 & 15.98839 \\
\hline 10 & 0.156705 & 58.36663 & 15.21442 & 9.695408 & 16.72354 \\
\hline
\end{tabular}

\section{Conclusions and Policy Recommendations}

This study examined the impact of fiscal policy on unemployment in South Africa using annual time series data for the period 1980 to 2010. A vector error correction model was used to determine the effects of fiscal policy aggregates on unemployment in South Africa. The fiscal policy aggregates considered in this study were government investment expenditure, government consumption expenditure and tax. Results from this study revealed that government consumption expenditure and tax have a positive impact on unemployment while government investment expenditure negatively affects unemployment in South Africa.

Several policy implications regarding the reduction of unemployment using the fiscal policy framework are recommended in this study. The study recommends the South African government to reduce the corporate tax rate from 28 per cent to figures below 20 per cent. Rates below 20 per cent as adopted by other OECD countries like Iceland, Turkey, Poland and Ireland (Perez, 2008) would help to promote further investments through expansions by existing businesses who currently suffer from massive corporate tax burdens. Lowering the corporate tax rate in South Africa would reduce the cost of production, increase GDP and promote employment. The government should also reduce personal income tax rates that are progressive to 40 per cent. As an emerging economy, South Africa should adopt policies that promote aggregate demand, boost economic growth and lower staggering rates of unemployment. Low income tax rates raise the average propensity to save as well as the households' propensity to consume thereby increasing aggregate demand. The government should emulate the relatively low personal income tax rates adopted by other emerging economies like Mexico and India (30 per cent), Brazil (27.5 per cent), Botswana ( 25 per cent) and Egypt 
(20 per cent). Furthermore, this study recommends the government to increase expenditure towards investment (such as infrastructure system development), and reduce government consumption expenditure (such as social grants) if it needs to alleviate the high rates of unemployment in the country.

\section{References}

Abrams, B. (1999). 'The effect of governments size on the unemployment rate', Public Choice, 99, pp. 395-401.

Agénor, P. (2004). 'Unemployment-Poverty Trade-offs', Policy Research Working Paper Series 3297, The World Bank.

Agénor P.R., Nabli, M.K., Yousef, T. and Jensen, H.T. (2007). 'Labour market reforms, growth, and unemployment in labour-exporting countries in the Middle East and North Africa', Journal of Policy Modelling, 29, pp. 277-309.

Aizenman, J. and Marion, N. (1993). 'Policy Uncertainty and Growth, Review of International Economics, 1, pp. 145-163.

Banerjee, A., Galiani, S., Levinsohn, J., McLaren, Z. and Woolard, I. (2008). 'Why has unemployment risen in the new South Africa?' NBER Working Paper 13167, National Bureau of Economic Research.

Barker, F. (2007). 'The South African Labour Market: Theory and Practice', Fifth Edition, Van Schaik Publishers.

Brett, E. (2005). 'From Corporatism to Liberalisation in Zimbabwe: Economic Policy Regimes and Political Crisis (1980-1997)', Crisis States Research Centre working papers series 1, 58. Crisis States Research Centre, London School of Economics and Political Science, London, UK.

Baxter, M. and King, J. (1993). 'Fiscal Policy in General Equilibrium', American Economic Review, 83, pp. 315 - 34.

Blanchard, O. J. (1987). 'Vector Autoregressive and Reality-Comment', Journal of Business and Economic Statistics, 5(4), pp. 449-451.

Buchanan, J. M. and Tullock, G. (1962). 'Public choice theory', University of Michigan Press

DTI (Department of Trade and Industry). 'Economic statistics', Reserve bank quarterly bulletin - selected data, Available at: http://apps.thedti.gov.za/econdb/default.asp.

Fatas, A. and Mihov, I. (2001). 'The Effects of Fiscal Policy on Consumption and Employment: Theory and Evidence', INSEAD and Centre for Economic Policy Research (CEPR), Discussion Paper 2760.

Feldmann, H. (2006). 'Government size and unemployment: Evidence from industrial countries', Public Choice, 127, pp. 3 - 4.

Friedman, M. (1969). 'The natural rate of unemployment', Chicago: Aldine.

Giavazzi, F. Jappelli, T. and Pagano, M. (2000). 'Searching for Non-Linear Effects of Fiscal Policy: Evidence from Industrial and Developing Countries', European Economic Review, 44, pp. 1259 - 1289.

Hercowitz, Z. and Strawczynski, M. (2004), 'Cyclical Ratcheting in Government Spending: Evidence from the OECD', Review of Economics and Statistics, 86, pp. 353-361.

Keynes, J. M. (1936). 'The General Theory of Employment, Interest, and Money', New York.

Kingdon, G. and Knight, J. (2007). 'Unemployment in South Africa, 1995-2003: Causes, Problems and Policies', Journal of African Economies, 16 pp. 813-848.

Klasen, S. and Woolard, I. (2008). 'Surviving Unemployment Without State Support: Unemployment and Household Formation in South Africa', Journal of African Economies, 18, pp. 1-51.

Kneller, R., Bleaney, M. and Gemmell, N. (1999). 'Fiscal Policy and Growth: Evidence from OECD Countries', Journal of Public Economics, 74, pp. 171-90.

Musgrave, R. (1959). 'Theory of fiscal policy', New York: McGraw Hill.

Pepinsky, T. (2007). 'Autocracy, Elections, and Fiscal Policy: Evidence from Malaysia', St Comp Int Dev, 42 pp 136-163.

Perez, M. (2008). 'Corporate Tax Rates by Country - OECD', Available at: http://alhambrainvestments.com/blog/2009/01/29/corporatetax-rates-by-country-oecd

Rose, R. (1981). 'What If Anything Is Wrong with Big Government?', Journal of Public Policy, 1(1), pp 5 - 36.

Schclarek, A. (2007). 'Fiscal Policy and Private Consumption in Industrial and Developing Countries', Journal of Macroeconomics, 29, pp 912-939.

StatsSA, (2010). 'Labour Force Survey, September 2010', Statistical Release P0210, Statistics South Africa, Pretoria.

Stryker, D., Cassim, F., Rajaratnam, B., Bhorat, H., Leibbrandt, M. and Plunkett, D. (2001). 'Increasing Demand for Labour in South Africa', Research Report, Equity and Growth through Economic Research/Public Strategies for Growth with Equity (EAGER/PSGE) project.

Tanzi, V. and Zee, H. (1997). 'Fiscal Policy and Long-Run Growth', Staff Papers - International Monetary Fund,. 44, pp 179-209.

Treasury, (1995 - 2011). 'National Budget Review' Available at: http://www.treasury.gov.za/documents/nationalbudgetreview.

Woolard, I. (2002). 'An Overview of Poverty and Inequality in South Africa', Working Paper, DFID (SA),

Available at: http://www.sarpn.org.za/documents/e0000006/Poverty_Inequality_SA.pdf.

Zenou, Y. (2008). 'Job search and mobility in developing countries: Theory and policy implications', Journal of Development Economics, 86, pp. 336-355. 


\section{Appendices}

Appendix Figure 1: Impulse response of unemployment

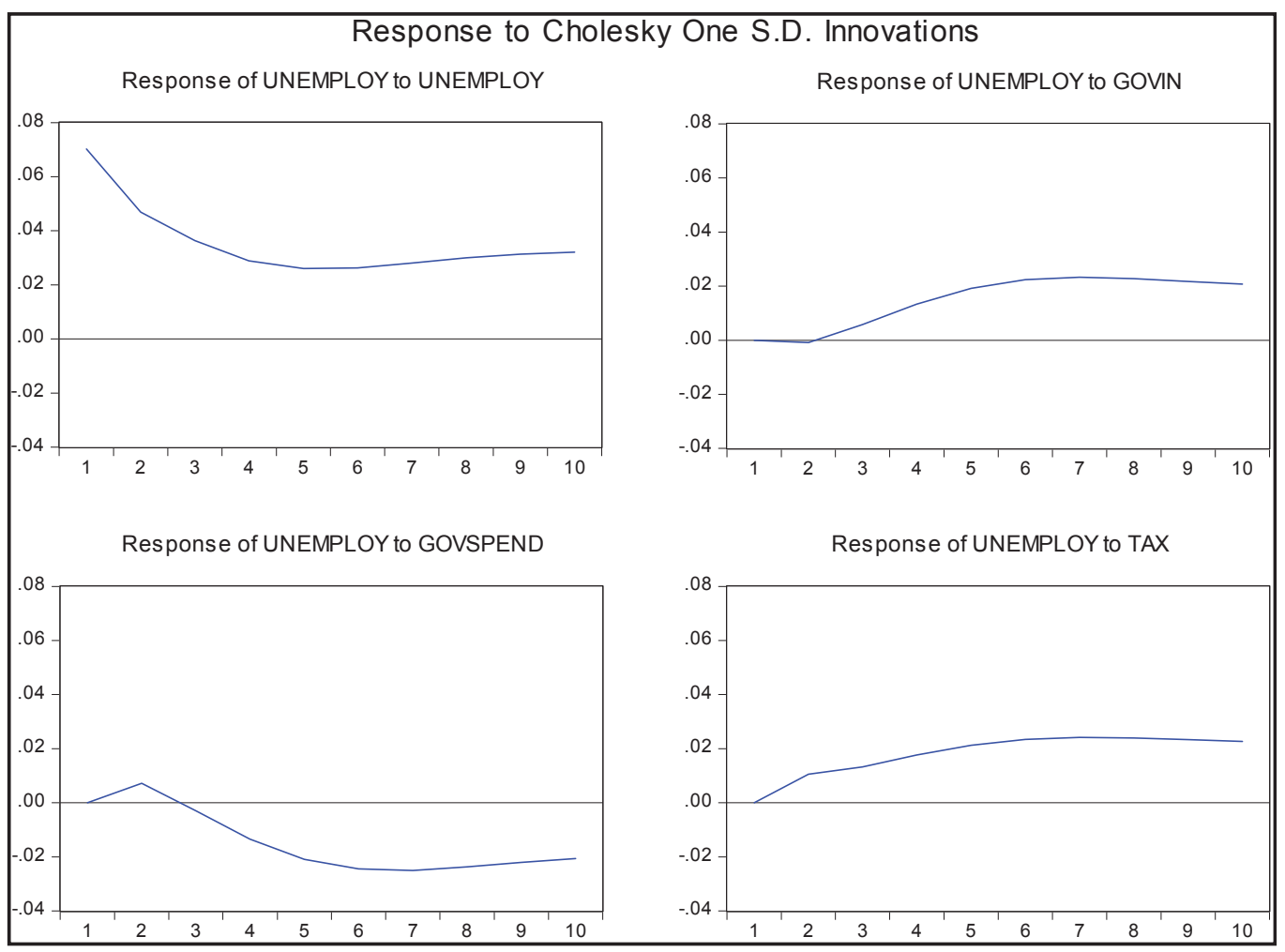


